\title{
Salinity Tolerance of Some Elite Rice Breeding Lines at Reproductive Stage
}

\author{
S Akter ${ }^{*}$, R Yasmeen ${ }^{1}$, H U Ahmed ${ }^{2}$, M R A Sarker ${ }^{2}$ and M S Rahman ${ }^{1}$
}

\begin{abstract}
Rice is relatively sensitive to salinity at reproductive stage. Screening of rice cultivars for salt tolerance at the reproductive stage is difficult at field conditions because of the heterogeneity of soil salinity. The present investigation aimed to characterize reproductive growth and yield potential of elite breeding lines in controlled saline environment at net house conditions. The experiment involved three advanced breeding lines, BR7100-R-6-6, IR78794-B-Sal29-1 and IR59418-7B-21-3 and a salt-tolerant check (BRRI dhan47) and susceptible check (BRRI dhan28) under four salinity levels $(0,4,8$, and $12 \mathrm{dS} / \mathrm{m})$ at reproductive stage. The factorial experiment was conducted in randomized complete block design with three replications. Salinity $\times$ genotypes demonstrated significant interactions on some yield contributing characters and grain yield Salinity stresses, at 8 and $12 \mathrm{dS} / \mathrm{m}$, decreased plant height, tiller and panicle numbers, panicle length, filled grain number and grain yields of all the tested genotypes in different magnitude. The breeding line IR59418-7B-21-3 performed greater tolerance to salinity than other tested lines and check varieties. At 8 dS/m IR59418-7B-21-3 produced $72 \%$ relative grain yield compared to that of $31 \%$ in BRRI dhan 47 . The breeding lines, BR7100-R-6-6 and IR78794-B-Sal29-1 produced 40 and 59\% relative grain yield respectively, at $8 \mathrm{dS} / \mathrm{m}$. At $12 \mathrm{dS} / \mathrm{m}$, all the tested genotypes produced less than $20 \%$ relative grain yield. Based on the salinity pressure $(8 \mathrm{dS} / \mathrm{m})$ at the reproductive stage, IR59418-7B-21-3 produced $68 \%$ higher yield than that of BRRI dhan47. BR7100-R-6-6 and IR78794-B-Sal29-1 out yielded BRRI dhan 47 by 45 and $49 \%$ respectively. All the three breeding lines performed better than that of BRRI dhan 47 in terms of salinity tolerance at the reproductive stage.
\end{abstract}

Keywords: Rice, salinity tolerance, reproductive stage, grain yield reduction

\section{INTRODUCTION}

The coastal areas of Bangladesh cover more than $30 \%$ of the cultivable lands of the country. About $53 \%$ of the coastal areas are affected by different degrees of soil salinity. Agricultural land use in those areas is very poor, which is much lower than country's average cropping intensity (Petersen and Shireen, 2001). The severity of salinity problem in Bangladesh increases due to climate change and the desiccation of the soil. Moreover, the dominant crop grown in the saline areas is local transplant Aman rice crop with low yields. So for the potential use of this vast coastal region the productivity of rice yield should be increased.

Salinity reduces the growth of plant through osmotic effects, reduces the ability of plants to take up water and this causes reduction in growth. There may be salt specific effects. $\mathrm{Na}^{+}$and $\mathrm{Cl}$ are the principal ions in majority of salt affected soils, which mainly affect plants growth. The roots of rice plants readily absorb $\mathrm{Na}^{+}$which are distributed in all plant organs to pose ion damage, osmotic stress and imbalance nutrition (Siringam et al., 2011). If excessive amount of salt enters the plant, the concentration of salt will eventually rise to a toxic level in older transpiring leaves causing premature senescence and reduce the photosynthetic leaf area of a plant to a level that cannot sustain growth (Munns, 2002; Shereen et al., 2005). Salinity appears to affect two plant processes - water relations and ionic relations. During initial exposure to salinity, plants experience water stress, which in turn reduces leaf expansion. During long-term exposure to salinity, plants experience ionic stress, which can lead to premature senescence of adult leaves (Amirjani, 2011). Salinity has three potential effects on plants: a) lowering of the water potential b) direct toxicity of any $\mathrm{Na}$ and $\mathrm{Cl}$ absorbed c) interference with the uptake of essential nutrients (Flowers and Flowers, 2005).

${ }^{1}$ Plant Physiology Division, 2Plant Breeding Division, Bangladesh Rice Research Institute (BRRI), Gazipur 1701, Bangladesh. *Corresponding author's email: salmabrri@gmail.com 

Rice is moderately sensitive to salt in the field as almost all the other crop species. The extent of damage depends on the severity of stress, growth conditions and plant sensitivity to salinity (Kant et al., 2007). Seedling and reproductive stage of rice is more sensitive to salinity stress. About eight salt tolerant varieties were developed for transplant Aman (T. Aman) as well as Boro which are moderately tolerant $(6-8 \mathrm{dS} / \mathrm{m})$. But more other salt tolerant varieties with desirable characteristics are also needed. It is essential to produce and improve stress tolerant rice plants suitable for cultivation in stress prone areas. However, the study was carried out to characterize reproductive growth and yield potential of elite breeding lines in controlled saline environment.

\section{MATERIALS AND METHODS}

The experiment was conducted in the net house of Plant Physiology Division of BRRI during Boro season. Three genotypes, BR7100-R-6-6, IR78794-B-Sal29-1 and IR59418-7B-21-3 with standard Boro check varieties BRRI dhan 28 and BRRI dhan47 were considered for this study. Plants were grown in perforated plastic pots (drilled and lined with canvas) filled with ground soil. The soil was fertilized with NPK and S@ 50, 25, 40 and $25 \mathrm{mg} / \mathrm{kg}$ soil. The pots were placed inside a bucket serving as water baths. Three to four pre germinated seeds were sown at the soil surface of each pot (Gregorio et al., 1997). Two weeks after seeding, seedlings were thinned to one per pot. After 65 days of sowing, salinization was made by adding $\mathrm{NaCl}$ in the bucket at 4, 8 and $12 \mathrm{dS} / \mathrm{m}$. Water level was maintained daily ( $1 \mathrm{~cm}$ above soil surface) by adding ordinary tap water. One set of plants was used as a control set (no salinity). The experiment was laid out in RCB design with three replications. At maturity, plants were harvested and yield and yield components were considered. To check the salinity level gained by the soil at the end of the experiment, sampling of soil and saturation paste extract was carried out and soil salinity was recorded after harvesting using EC meter. Analysis of variance (ANOVA) was performed for all experimental data and mean differences were compared by using LSD test through Crop STAT-C.

\section{RESULTS AND DISCUSSION}

Analysis of variance showed significant variety and salinity level interaction in tiller per hill, filled grain per panicle, sterility percent and grain per plant (Table 1).

Table1. Analysis of variance for growth and yield related traits as affected by different salinity level.

\begin{tabular}{|c|c|c|c|c|c|c|c|c|}
\hline $\begin{array}{c}\text { Sources of } \\
\text { variation }\end{array}$ & $\mathrm{df}$ & $\begin{array}{c}\text { Tiller } \\
\text { number/pot }\end{array}$ & $\begin{array}{c}\text { Panicle } \\
\text { number/pot }\end{array}$ & $\begin{array}{l}\text { Plant ht } \\
(\mathrm{cm})\end{array}$ & $\begin{array}{c}\text { Panicle } \\
\text { length }(\mathrm{cm})\end{array}$ & $\begin{array}{c}\text { Filled grain } \\
\text { number }\end{array}$ & $\begin{array}{c}\text { Sterility } \\
(\%)\end{array}$ & $\begin{array}{c}\text { Grain yield } \\
\text { (g/pot) }\end{array}$ \\
\hline Replication (R) & 3 & $27.74^{\mathrm{NS}}$ & $11.12^{* *}$ & $34.51^{\mathrm{NS}}$ & $8.50^{\mathrm{NS}}$ & $92593.6^{\mathrm{NS}}$ & $181.10^{\mathrm{NS}}$ & $41.47^{*}$ \\
\hline Genotypes (G) & 4 & $67.37^{* *}$ & $38.34^{* *}$ & $1560.3^{* *}$ & $109.52^{* *}$ & $383041^{* *}$ & $1436.6^{* *}$ & $87.61^{* *}$ \\
\hline Treatment $(\mathrm{T})$ & 3 & $510.74^{* *}$ & $570.18^{* *}$ & $4723.3^{* *}$ & $177.28^{* *}$ & $0.56^{* *}$ & $3326.7^{* *}$ & $2311.1^{* *}$ \\
\hline GxT & 12 & $58.22^{* *}$ & $22.73^{N S}$ & $785.57^{* *}$ & $51.41^{* *}$ & $134487^{* *}$ & $573.86^{* *}$ & $39.27^{* *}$ \\
\hline Error & 57 & 16.64 & 12.47 & 174.63 & 13.24 & 45522.2 & 181.21 & 11.87 \\
\hline $\mathrm{CV}(\%)$ & & 24.8 & 26.2 & 16 & 18.4 & 24.6 & 34.3 & 22.5 \\
\hline
\end{tabular}

* and ${ }^{* *}$ indicate significance at the $5 \%$ and $1 \%$ levels, respectively and ns: non-significant.

\section{Plant height}

Salinity levels significantly affected plant height of tested rice genotypes and salinity $\times$ genotype interaction demonstrated significant effect (Fig. 1). At $0 \mathrm{dS} / \mathrm{m}$ salinity level, the highest plant height was obtained with BRRI dhan47 and the lowest in IR59418-7B-21-3. Increasing salinity level to $4 \mathrm{dS} / \mathrm{m}$, BRRI dhan 47 slightly reduced plant height while BRRI dhan28, BR7100-R-6-6 and IR78794-B-Sal29-1 slightly increased plant height. At $8 \mathrm{dS} / \mathrm{m}$, plant height in all the tested genotypes decreased but the magnitude of decreasing was the highest in BRRI dhan28 and the lowest in IR59418-7B-21-3. Increasing salinity level to $12 \mathrm{dS} / \mathrm{m}$, plant height decreased in all genotypes but BRRI dhan28 decreased more drastically than other genotypes. Similar result was reported by Islam et al. (2007) and WeonYoung et al. (2003) in different genotypes and cultivars of rice. The results indicate that the effect of salinity on plant elongation of different varieties were different, which might 
be due to genetic potential of the varieties. Shalhevet (1995) reported that salinity generally reduces shoot growth of crops more than root growth, based on dry weight rather than length measurements.

\section{Number of panicles}

Panicle numbers affected significantly for the tested genotypes at varying salinity levels. But the interaction effect of genotypes and salinity was not significant (Fig. 1). The maximum number of panicle was obtained from control which was reduced gradually to 4 and $8 \mathrm{dS} / \mathrm{m}$ salinity level and became minimum at $12 \mathrm{dS} / \mathrm{m}$ level of soil salinity. Genotype BR7100-R-6-6, IR59418-7B-21-3 and IR78794-B-Sal29-1 produced more panicles than BRRI dhan 28 at all salinity levels. Akbar et al. (1972) and Islam et al. (2007) have also reported similar results. More salt tolerant ability may lead to the less reduction of panicle number.

\section{Sterility percentage of spikelet}

Significant influence of salinity on spikelets sterility for the tested genotypes was also observed in this experiment. The interaction between salinity and genotypes on the sterility percentage showed significant effect (Fig. 1). Sterility percentage was similar for all the genotypes at control condition. Spikelets sterility increased gradually with the salinity level to $4 \mathrm{dS} / \mathrm{m}$ but BR7100-R-6-6 increased less and BRRI dhan28 increased more than other genotypes. At $8 \mathrm{dS} / \mathrm{m}$, increasing rate was maximum for BRRI dhan 28 followed by BRRI dhan47. Sterility percentage increased with the increasing level of salinity to $12 \mathrm{dS} / \mathrm{m}$ but increasing trend was maximum for BRRI dhan28 and minimum for BR7100-R-6-6 than other genotypes. Saleque et al. (2005) reported genotypic variation of rice in sterility percentage due to soil and water salinity. The reduced spikelet fertility or increased sterility might be due to the failure of grain formation in rice grain which could be caused by lack of pollen viability. Khatun et al. (1995) earlier reported that salinity reduces pollen viability and seed set.

\section{Number of filled grain per panicle}

The number of filled grain per panicle varied significantly due to the effect of salinity. The interaction between salinity and genotypes on the number of filled grain also showed significant variation (Fig. 2). At $0 \mathrm{dS} / \mathrm{m}$, BR7100-R-6-6 produced the highest number of grain per panicle, however, other genotypes showed insignificant variation in filled grain number. With the increase of salinity level to 4 $\mathrm{dS} / \mathrm{m}$, filled grain number remained stable for IR59418-7B-21-3， BR7100-R-6-6， IR78794-BSal29-1 and BRRI dhan47 except BRRI dhan28 which showed decreasing trend compared to control. At $8 \mathrm{dS} / \mathrm{m}$, filled grain number decreased for all the genotypes but the magnitude of decreasing was the highest in BRRI dhan 28 followed by BRRI dhan 47 and the lowest in IR59418-7B-21-3, BR7100-R-6-6, IR78794-B-Sal29-1. At $8 \mathrm{dS} / \mathrm{m}$, the relative filled grain number was the highest $(86 \%)$ in IR594187B-21-3 followed by $81 \%$ in IR78794-B-Sal29-1 and $58 \%$ in BR7100-R-6-6. BRRI dhan 47 and BRRI dhan28 produced the relative grain number of 41 and $21 \%$ respectively, at $8 \mathrm{dS} / \mathrm{m}$. Increasing level of salinity to $12 \mathrm{dS} / \mathrm{m}$ reduced filled grain number for all the genotypes. The relative number of grain per panicle dropped to $22 \%$ in IR59418-7B-21-3, 19\% in BR7100-R-6-6 and only 9\% in IR78794-B-Sal29-1 respectively at $12 \mathrm{dS} / \mathrm{m}$. Increased salinity resulted in decreased total number of filled grains per panicle reported by Hassan et al. (2012) and Hasanuzzaman et al. (2009) in rice. This result also was supported by Asch et al., (1999) who worked with eight rice cultivars and found that cultivars differed in their salt uptake and tolerant cultivars had lower salt effect on yield and yield components than the susceptible ones. 
Plant ht (cm)

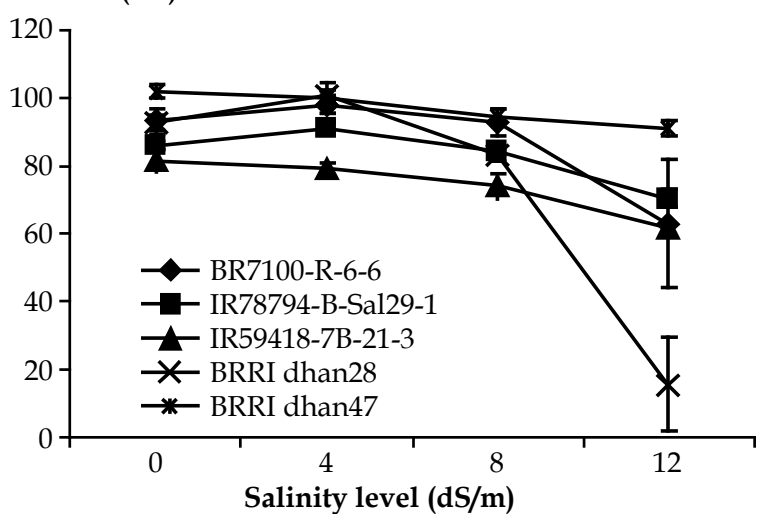

Panicle (no./hill)

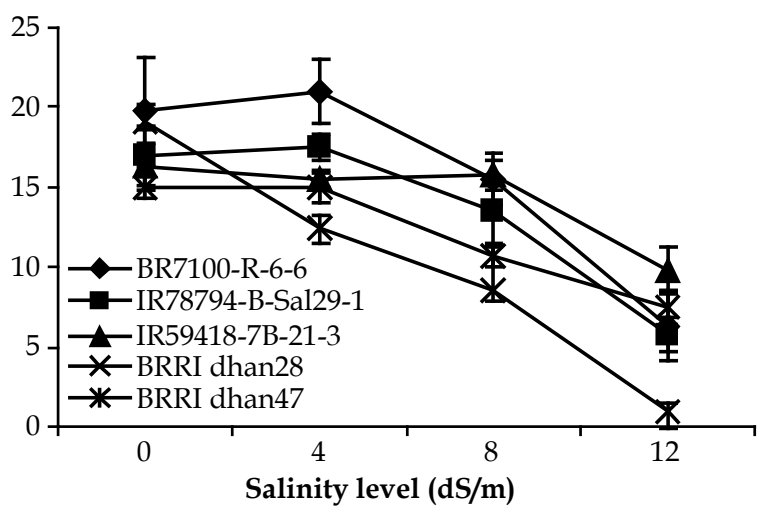

Sterility (\%)

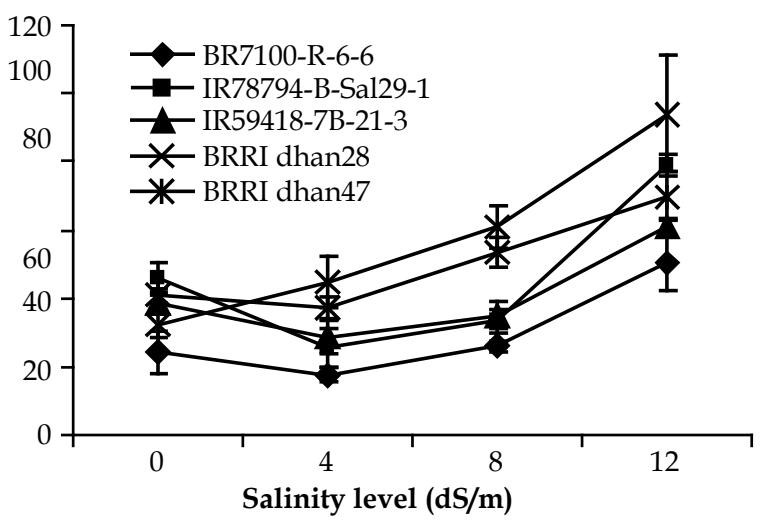

Fig. 1. Effect of salinity level on plant height, panicle production and sterility percentage in rice genotypes.

\section{Grain yield per hill}

Salinity $\times$ genotype demonstrated significant effect on grain yield (Fig. 2). At $0 \mathrm{dS} / \mathrm{m}$ salinity level, BR7100-R-6-6 produced the highest grain yield followed by BRRI dhan47 and IR59418-7B21-3 gave the lowest yield. At salinity level to 4 $\mathrm{dS} / \mathrm{m}$, except IR78794-B-Sal29-1, all the tested genotypes decreased grain yield by $11-14 \%$. Increasing salinity level to $8 \mathrm{dS} / \mathrm{m}$, rice yield reduced significantly in all the genotypes, however, the magnitude of decrease was the highest in BRRI dhan28 (79\%) followed by BRRI 36 Akter et al

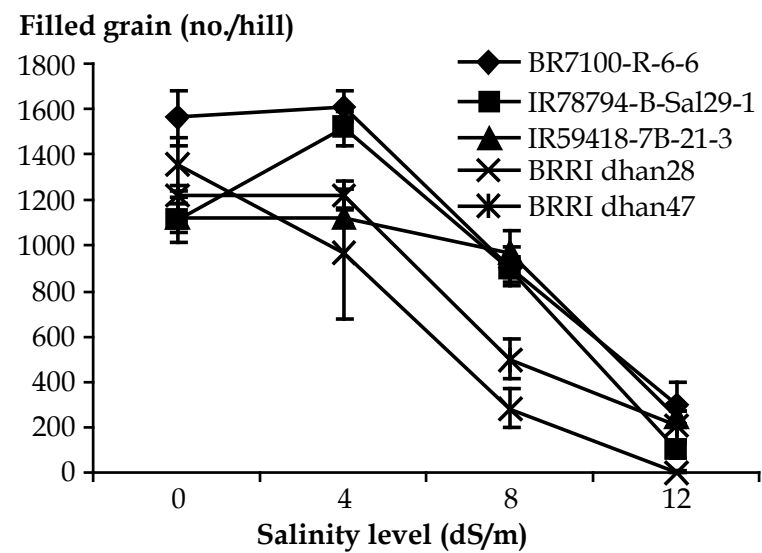

Days to heading (day)

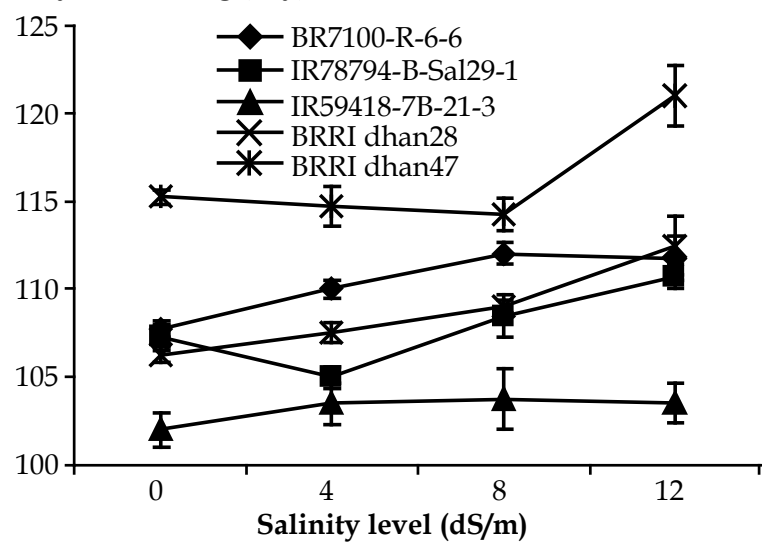

Grain yield/hill (g)

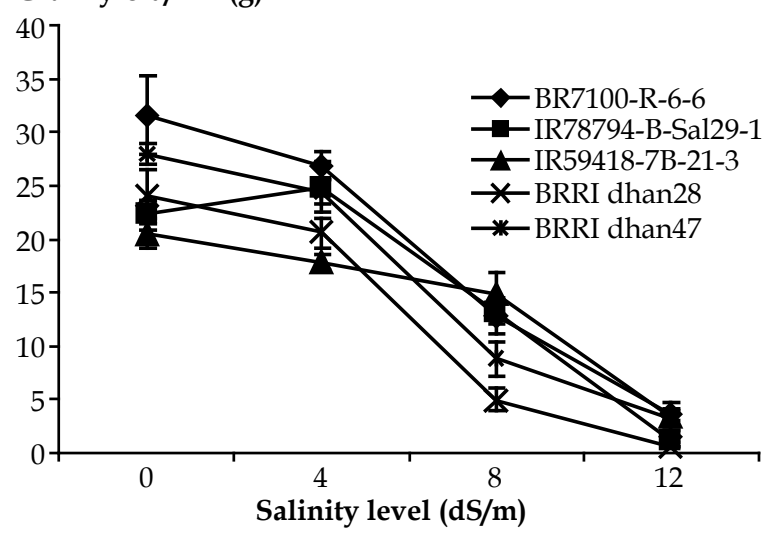

Fig. 2. Effect of salinity level on filled grain, days to maturity and grain yield in some rice genotypes.

dhan47 (69\%). The tested lines BR7100-R-6-6, IR78794-B-Sal29-1 and IR59418-7B-21-3 showed a reduction of grain yield by 60,41 and $28 \%$ respectively, at salinity level of $8 \mathrm{dS} / \mathrm{m}$. At $8 \mathrm{dS} / \mathrm{m}$, IR59418-7B-21-3 gave significantly higher yield than other genotypes. Increasing salinity level to $12 \mathrm{dS} / \mathrm{m}$, yield reduction increased to 83-95\% in BR7100-R-6-6, IR78794-BSal29-1 and IR59418-7B-21-3 compared to 89\% in BRRI dhan 47 and $100 \%$ in BRRI dhan 28 . The yield of BR7100-R-6-6 and IR59418-7B-21-3 was very similar to BRRI dhan 47 at stress level 12 
$\mathrm{dS} / \mathrm{m}$. WeonYoung et al. (2003) reported that grain yield decreased with raising salinity. Islam et al. (2007) also found similar result.

\section{Soil salinity after maturity}

After application of saline water, the soil slowly absorbed the salt and the salinity developed in the soil and finally attained an equilibrium condition between water and soil salinity. Soil salinity decreased gradually at the end of crop. The level of salinity developed in the soil was $\sim 3.0,4.5$ and $\sim 8.5 \mathrm{dS} / \mathrm{m}$ for 4,8 and $12 \mathrm{dS} / \mathrm{m}$ application level respectively.

\section{CONCLUSIONS}

From the current investigation it is revealed that among the tested genotypes, two elite lines namely BR7100-R-6-6 and IR59418-7B-21-3 performed better than BRRI dhan 47 at $8 \mathrm{dS} / \mathrm{m}$ levels of salinity stress at the reproductive stage and these lines may be cultivated in saline areas or used as donors for future breeding programme.

\section{REFERENCES}

Ashraf, M and P J C Harris. 2004. Potential biochemical indicators of salinity tolerance in plants. Plant Sci. 166, 3-16.

Amirjani, M R. 2011. Effect of salinity stress on growth, sugar content, pigments and enzyme activity of rice. Int. J. Bot., 7: 73-81.

Flowers, T J and S A Flowers. 2005. Why does salinity pose such a difficult problem for plant breeders? Agr.Water Manage. 78: 15-24.

Gregorio, G B, S Dharmawansa and D M Rhulyx. 1997. Screening Rice for Salinity Tolerance. International Rice Research Institute, P.O. Box 933, Manila 1099, Philippines. IRRl Discussion Paper Series no. 22.

Hassan, E R, A Farshid and R Mojtaba. 2012. Response of rice to different salinity levels during different growth stages. Research J. of Applied Sci., Engineering and Technology. 4(17): 3040-3047

Hasanuzzaman, M, F Masayuki, M N Islam, K U Ahamed and K Nahar. 2009. Performance of four irrigated rice varieties under different levels of salinity stress. International J. Int. Bio.6 (2): 85-90.
Islam, M Z, M A Baset Mia, M R Islam and A Akter. 2007. Effect of different saline levels on growth and yield attributes of mutant rice. J. Soil Nature. 1 (2): 18-22.

Khatun, S and T J Flowers. 1995. Effects of salinity on seed set in rice. Plant Cell Environment. 18: 61-67.

Karim, Z and A Iqbal. (2001). Impact of land degradation in Bangladesh. Changing scenario in agricultural land use. Compilation of data from the geographical information system (GIS) project. Bangladesh Agricultural Research Council publication. pp. 106.

Kant, S, P Kant, H Lips and S Barak. 2007. Partial substitution of $\mathrm{NO}_{3}{ }^{-}$by $\mathrm{NH}_{4}{ }^{+}$fertilization increases ammonium assimilating enzyme activities and reduces the deleterious effects of salinity on the growth of barley. Journal of Plant Physiology. v.164, p.303-311.

LingHe, Z, M C Shannon and L H Zeng. 2000. Salinity effects on seedling growth and yield components of rice. Crop Sci., 40(4): 996-1003.

Munns, R. 2002. Comparative physiology of salt and water stress. Plant Cell Environ. 25: 239-250.

Marassi, J E, M Collado, Benavidez, M J Arturi and J J N Marassi. 1989. Performance of selected rice genotypes in alkaline, saline and normal soils and their interaction with climate factor. Intl. Rice Res. Newsl., 14(6): 10-11.

Mori, I K and T Kinoshita. 1987. Salt tolerance of rice callus clones. Rice Genet. Newslett. 4: 112-113.

Munns, R. 2002. Comparative physiology of salt and water stress. Plant Cell Environ. 25, 239-250.

Petersen, L and S Shireen. 2001. Soil and water salinity in the coastal area of Bangladesh. Soil Resource Development Institute.

Saleque, M A, N N Choudhury, S M R Karim and G M Panaullah. 2005. Mineral nutrition and yield of four rice genotypes in the farmers' fields of salt-affected soil. J. Plant Nutri. 28: 865-875.

Shalhevet, J. 1995. Root and shoot growth responses to salinity in maize and soybean. Agron J. 87:512-516.

Shannon, M C, J D Rhoades, J H Draper, S C Scardaci and M D Spyres. 1998. Assessment of salt tolerance in rice cultivars in response to salinity problems in California. Crop Sci., 38: 394-398.

Shereen, A, S Mumtaz, S Raza, M A Khan and S Solangi. 2005. Salinity effects on seedling growth and yield components of different inbred rice lines. Pak. J. Bot. 37(1): 131-139.

Siringam, K, N Juntawong, S Cha-um and C Kirdmanee. 2011. Salt stress induced ion accumulation, ion homeostasis, membrane injury and sugar contents in salt-sensitive rice (Oryza sativa L. spp. indica) roots under isoosmotic conditions. Afr. J. Biotechnol., 10(8): 1340-1346.

WeonYoung, C, L KyuSeong, K JongCheo, C SongYeol and C DonHyang. 2003. Critical saline concentration of soil and water for rice cultivation on a reclaimed saline soil. Korean J. Crop Sci. 48(3): 238-242. 